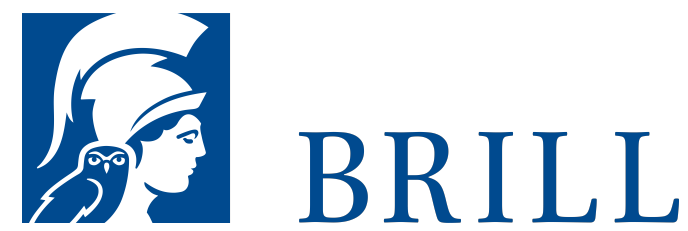

\title{
Gegen den Uhrzeigersinn
}

Ekklesiologie kirchlicher Gegenwarten

Author: Gregor Maria Hoff

Die katholische Kirche lebt in disparaten Gegenwarten. Im Umbruch ihrer Traditionen steht sie auf dem Prüfstand. Ihre Einheit findet sie, wo sie auf die schöpferische Lebensmacht Gottes setzt. Das verlangt, immer wieder gegen den Uhrzeigersinn vorzugehen: gegen Erwartungen und Festlegungen.

Die katholische Kirche bezieht im 21. Jahrhundert Räume und Glaubenswelten, die ihre Einheit auf Zerreißproben stellt: zwischen religiösen Kulturen und Glaubensformen, in Interpretationskonflikten zwischen Tradition und Traditionalismus, zwischen unausweichlichen Relativierungen und der Angst vor Relativismus. Der vorliegende Band gibt der Gleichzeitigkeit verschiedener Gegenwarten Raum, erschließt aber auch die Ungleichzeitigkeiten. Sie setzen Widersprüche und Verwerfungen frei, zeigen aber auch die Transformationsprozesse an, in denen die Kirche ihre Tradition unter dem Druck von Krisenerfahrungen neu bestimmen muss. Es gilt, sie in einer Ekklesiologie kirchlicher Gegenwarten lesbar zu machen und dabei den Eigensinn kirchlichen Glaubens und Handelns angesichts der Probleme unserer Zeit zur Geltung zu bringen - immer auch gegen den Uhrzeigersinn eingespielter Erwartungen und Abläufe.

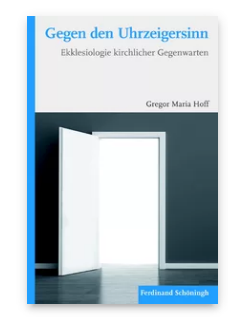

Pages: 272 Seiten, 2 s/w

Abb.

Language:

German

Subjects:

General, Theology and

World

Christianity

Publisher: Brill|

Schöningh

E-Book (PDF)

Released online:

24 Nov 2017

ISBN: 978-3-

657-78793-7

List price

Paperback

Publication date:

10 Nov 2017

ISBN: 978-3-

5o6-78793-4

List price 
Biographical Note

Gregor Maria Hoff ist seit 2003 Professor für

Fundamentaltheologie und Ökumenische Theologie an der

Universität Salzburg.

For more information see brill.com

Order information: Order online at brill.com +44 330 333 0049 | customerservices@brill.com Submission information: brill.com/authors

Titles published by Brill | Fink, Brill | mentis or Brill | Schöningh: +49(o)71 5413279216 | brill@brocom.de 